\title{
Reproductive Factors and Risk of Ovarian Cancer
}

\author{
Reproduktive Faktoren und das Ovarialkarzinomrisiko
}

Authors

Affiliation

\author{
S. Schüler, M. Ponnath, C. Lattrich, O. Ortmann
}

Universitätsfrauenklinik Regensburg, Caritas-Krankenhaus St. Josef, Regensburg

\author{
Key words \\ - reproductive factors \\ - ovarian malignancy \\ - parity \\ - lactation \\ - infertility \\ - PCO syndrome
}

\section{Schlüsselwörter}

- reproduktive Faktoren

- Ovarmalignom

- Parität

- Laktation

- Infertilität

- PCO-Syndrom

\section{received 25.4.2013 \\ revised $\quad 3.5 .2013$ \\ accepted 7.5.2013}

Bibliography

DOI http://dx.doi.org/

10.1055/s-0032-1328686

Geburtsh Frauenheilk 2013; 73 :

640-648 ๑ Georg Thieme

Verlag KG Stuttgart · New York . ISSN 0016-5751

\section{Correspondence}

Dr. Susanne Schüler

Universitätsfrauenklinik

Regensburg,

Caritas-Krankenhaus St. Josef

Landshuter Straße 65

93053 Regensburg

sschueler@caritasstjosef.de

\section{Abstract \\ $\nabla$}

Ovarian epithelial cancer (OEC) is the most lethal gynaecological malignancy and the sixth most common cancer among women in industrialised countries. This review summarises the current knowledge on the role of reproductive factors for the development of OEC. Recent studies have shown that OECs represent a diverse group of cancers. This is partly reflected in the results of epidemiological and clinical studies which have investigated the impact of various reproductive factors on the risk of developing OEC. Fewer ovulatory cycles, parity and lactation were found to decrease the risk for OEC, whereas the association between infertility and ovarian cancer has not yet been fully elucidated and further investigation is required. None of the proposed hypotheses on the development of ovarian cancer fully explains the epidemiological and clinical findings of the association between reproductive factors and OEC development. Further research is warranted which would focus more on the clinical and genetic diversity of OECs to obtain a better understanding of the pathogenesis.

\section{Introduction}

Ovarian epithelial cancer (OEC) is the most lethal gynaecological malignancy and the sixth most common cancer among women in industrialised countries [1]. Because of its potential for aggressive local invasion and the lack of sensitive methods for early screening, around $75 \%$ of all ovarian cancers are diagnosed at an advanced stage. Around $90 \%$ of all ovarian malignancies are epi-

\section{Zusammenfassung \\ $\nabla$}

Das epitheliale Ovarialkarzinom ist das gynäkologische Malignom mit der höchsten Letalitätsrate und die sechsthäufigste Krebserkrankung der Frau in den Industrieländern. Diese Übersichtsarbeit fasst die aktuellen Kenntnisse zur Rolle reproduktiver Faktoren bei der Entwicklung von Ovarialkarzinomen zusammen. Aktuelle Studien zeigen, dass es sich bei Ovarialkarzinomen um heterogene Tumoren handelt. Dies wird teilweise auch in Resultaten epidemiologischer und klinischer Studien reflektiert, welche die verschiedenen Effekte reproduktiver Faktoren auf das Ovarialkarzinom untersuchten. Für eine kurze Lebensspanne mit menstruellen Zyklen, Parität und Laktation wurde eine negative Assoziation mit dem Ovarialkarzinomrisiko gezeigt, wohingegen der Zusammenhang zwischen Infertilität und Ovarialkarzinomen nicht gänzlich geklärt ist. Keine der bisher formulierten Hypothesen zur Entwicklung von Ovarialkarzinomen kann die epidemiologischen und klinischen Erkenntnisse zum Zusammenhang zwischen reproduktiven Faktoren und der Ovarialkarzinomentwicklung eindeutig erklären. Weitere wissenschaftliche Bemühungen sind erforderlich, die mehr Gewicht auf die genetische Vielfalt von Ovarialkarzinomen legen, damit ein detailliertes Verständnis ihrer Pathogenese erreicht werden kann.

\section{Einleitung}

Das Ovarialkarzinom ist das gynäkologische Malignom mit der höchsten Letalitätsrate und die sechsthäufigste Krebsform bei Frauen in Industrieländern [1]. Aufgrund seines aggressiven lokalen Invasionspotenzials und dem Fehlen sensitiver Früherkennungsmethoden werden $75 \%$ aller Ovarialkarzinome erst in fortgeschritten Stadien diagnostiziert. Etwa 90\% aller ovariellen Malignome sind epitheliale Kar- 
thelial cancers. They are classified according to their predominant patterns of differentiation. Serous ovarian tumours derive from tubal epithelium. The epithelium of mucinous tumours exhibits either an intestinal or endocervical phenotype. Endometrioid tumours are characterised by epithelial and stromal elements resembling those of the endometrium. Clear cell carcinomas are biologically similar to endometrioid carcinomas; they are formed by cytoplasm-poor cells with prominent nuclei which protrude into the luminal space. As their incidence is low, transitional cell, squamous and mixed epithelial carcinomas are not discussed in this review.

Recent studies have introduced a dualistic model for the classification of ovarian cancers [2]. Type I tumours include low-grade serous, low-grade endometrioid, clear cell and mucinous ovarian carcinomas. They are generally indolent, slow to proliferate and have a good prognosis. High-grade serous ovarian cancer is aggressive, has a high proliferative activity, and presents at an advanced stage, making it a classic type II tumour.

Hormone receptor expression in ovarian cancers points to the role of endocrine factors in initiating and promoting the process of carcinogenesis in ovarian cancer. In recent years the role of reproductive factors for the development of ovarian cancer has been controversially discussed. This review summarises the current scientific knowledge and explains the role of reproductive factors for the development of ovarian cancer. The association between endocrine interventions and ovarian cancer is not discussed here.

\section{Hypotheses for the Development of Ovarian Cancer} $\nabla$

\section{Ovulation theory}

Frequent and regular ovulation increases the risk of developing ovarian cancer. This hypothesis was put forward in 1971 by Fathalla et al. The idea was that repeated ovulation-induced trauma to ovarian surface epithelium contributes to cancer development because increased cell proliferation is necessary to repair lesions of ovarian surface epithelium, requiring an increased DNA synthesis rate. This, in turn, increases the risk of mutations which can initiate or promote the process of carcinogenesis $[3,4]$.

\section{Fallopian tube theory}

According to this hypothesis, high-grade serous ovarian carcinomas develop in the Fallopian tubes [5]. Serous tubal intraepithelial carcinomas (STIC) are found in $50-60 \%$ of all sporadically occurring ovarian cancers [6]. As the same p53 mutations have been detected in STICs as in concurrent high-grade serous ovarian cancer, a clonal relationship must be considered [7]. Investigation of the gene expression profile of high-grade serous ovarian cancer has demonstrated greater affinity with the epithelium of Fallopian tubes than with ovarian surface epithelium [8]. Repeated rupture of ovarian surface epithelium during ovulation releases follicular liquid which contains free radicals. Alternatively, changes in the micro milieu can damage the tubal epithelium, which, in turn, may result in repeat destruction of DNA and malignant transformation [5,9]. The milieu could explain why these malignant cells prefer the ovaries for proliferation and invasion; this suggestion is currently being investigated [5]. zinome. Sie können über ihr prädominierendes Differenzierungsmuster klassifiziert werden. Seröse Ovarialtumoren leiten sich vom Tubenepithel ab. Das Epithel muzinöser Tumoren besitzt entweder einen intestinalen oder einen endozervikalen Phänotyp. Endometrioide Tumoren werden durch epitheliale und stromale Elemente charakterisiert, die denen des Endometriums ähneln. Die biologisch den endometrioiden Karzinomen nahestehenden klarzelligen Karzinome werden durch zytoplasmaarme Zellen mit großen, luminal vorspringenden Zellkernen gebildet. Aufgrund ihrer niedrigen Inzidenz sind transitionalzellige, squamöse und epitheliale Mischtumoren nicht Gegenstand dieses Artikels.

Aktuelle Arbeiten haben eine duale Klassifizierung von Ovarialkarzinomen eingeführt [2]. Low-grade seröse, low-grade endometrioide, klarzellige und muzinöse Ovarialkarzinome werden als Typ-I-Tumoren zusammengefasst. Sie zeichnen sich durch ihr eher indolentes Verhalten, ihr langsames Proliferationsmuster und ihre gute Prognose aus. Der klassische Vertreter der Typ-II-Tumoren ist das highgrade seröse Ovarialkarzinom, mit seinem aggressiven Potenzial, seiner hohen proliferativen Aktivität und der Diagnosestellung in fortgeschrittenen Stadien.

Die Expression von Hormonrezeptoren in Ovarialkarzinomen legt eine Rolle endokriner Faktoren bei der Initiierung und Progression der Karzinogenese des Ovarialkarzinoms nahe. In den letzten Jahren wurde die Rolle reproduktiver Faktoren bei der Entstehung eines Ovarialkarzinoms kontrovers diskutiert. Diese Übersichtsarbeit fasst den aktuellen Kenntnisstand der Wissenschaft zusammen und erklärt die Rolle reproduktiver Faktoren bei der Entstehung von Ovarialkarzinomen. Nicht eingegangen wird auf den Zusammenhang zwischen endokrinen Interventionen und dem Ovarialkarzinomrisiko.

\section{Hypothesen für die Genese des Ovarialkarzinoms \\ $\nabla$}

Ovulationshypothese

Häufige und konstante Ovulationen erhöhen das Risiko für ein Ovarialkarzinom. Diese Theorie wurde 1971 von Fathalla et al. aufgestellt und stützt sich auf repetitive ovulatorische Traumata am ovariellen Oberflächenepithel. Zur Reparatur der Läsionen des Oberflächenepithels ist eine vermehrte Proliferation der Zellen und somit eine erhöhte DNA-Syntheserate erforderlich. Dadurch ist das Risiko für das Auftreten von Mutationen erhöht, was zur Initiierung oder Progression der Karzinogenese führen kann [3,4].

\section{Tuba-uterina-Hypothese}

Gemäß dieser Theorie entsteht das high-grade seröse Ovarialkarzinom in der Tuba uterina [5]. In 50-60\% aller sporadisch auftretenden Ovarialkarzinome werden seröse tubare intrapitheliale Karzinome (STIC) gefunden [6]. Da in den STICs die gleichen p53-Mutationen detektiert wurden wie im simultanen high-grade serösen Ovarialkarzinom, muss eine klonale Beziehung diskutiert werden [7]. Untersuchungen des Genexpressionsprofils von High-grade serösen Ovarialkarzinomen zeigen eine größere Ähnlichkeit mit dem Epithel der Tuba uterina als mit dem ovariellen Oberflächenepithel [8]. Die Ruptur des ovariellen Oberflächenepithels während der Ovulation führt zur Freisetzung von Follikelflüssigkeit. Diese enthält freie Radikale oder führt durch eine Veränderung des Mikromilieus zu einer Schädigung des Tubenepithels, was wiederum wiederholte Zerstörung der DNA und maligne Transformierung zur Folge haben kann $[5,9]$. Warum diese malignen Zellen die Ovarien für ihre weitere Ausbreitung und Invasion bevorzugen, könnte durch das besondere Milieu erklärt werden und ist noch Gegenstand aktueller Forschung [5]. 


\section{Gonadotropin theory}

According to the hypothesis of Cramer and Welch, excessive gonadotropin stimulation of ovarian stroma increases the risk for ovarian cancer [10]. Stimulation of the stroma by gonadotropins results in high local oestrogen concentrations which affect the inclusion cysts in the ovarian stroma. This theory is based on the observation of Biskind and Biskind, who reported in 1944 that transplantation of ovaries into the splenic pulp of adult rats resulted in the development of ovarian tumours. Tumorigenesis was attributed to inactivation of oestrogen in the liver with a consequent elevation of gonadotropin levels due to the lack of steroid feedback [11]. The work of Blaakaer et al. additionally supports this hypothesis. In their study they used mice with a congenital oocyte deficiency which were known to develop bilateral complex tubular adenomas. Plasma levels of LH and FSH were found to increase fourfold in these mice during tumorigenesis. If the animals were treated with GnRH agonists, tumorigenesis was prevented in $100 \%$ of cases [12]. This theory is additionally supported by the finding that postmenopausal women with high gonadotropin levels have an increased risk for ovarian cancer.

\section{Androgen/progesterone theory}

In 1998, Risch postulated that androgens can increase the risk for ovarian cancer, while progesterone can lower the risk [13]. Ovarian surface epithelium expresses androgen receptors. Relatively high androgen concentrations have also been detected in the epithelial ovarian stroma which surrounds epithelial inclusion cysts, believed to be where ovarian cancer originates. Testosteronedependent growth of ovarian tumours has been demonstrated in an animal model $[14,15]$. Significantly higher androstenedione and dehydroepiandrostenedione levels were found in women with ovarian cancer [16]. Women with symptoms associated with increased androgen serum levels such as acne, hirsutism or greater waist-to-hip ratio have a higher risk of developing ovarian cancer [17-19]. However, this theory is still controversially discussed after more recent studies did not find any association between androgen serum levels prior to diagnosis, serum levels of sexual hormone-binding globulin (SHBG) and the risk for ovarian cancer [20-22].

Pregnancy is well known to be a protective factor against ovarian cancer, and serum progesterone levels during pregnancy are high. The assumption that progesterone may be a protective factor against ovarian cancer is supported by the fact that gestagencontaining oral contraceptives reduce the risk of developing ovarian cancer.

\section{Reproductive Factors}

$\nabla$

\section{Age at menarche and age at menopause}

A recent meta-analysis demonstrated a significant inverse association between age at menarche and the risk of developing ovarian cancer (RR 0.85, 95\% CI 0.75-0.97) [23]. Women with an estimated cumulative duration of menstrual cycles of more than 36 years were found to have a significantly higher risk for ovarian cancer than those with a cumulative menstrual lifespan of less than 27 years [24]. Braem et al. calculated a reduction in risk of $3 \%$ for every year by which the cumulative menstrual lifespan was reduced (HR 0.97, 95\% CI 0.95-0.99) [25]. This association was only shown for non-mucinous tumours [26,27]. Postmenopausal women were reported to have a twofold increased risk of

\section{Gonadotropin-Hypothese}

Laut der Theorie von Cramer und Welch erhöht eine exzessive Stimulation des ovariellen Stromas durch Gonadotropine das Risiko, ein Ovarialkarzinom zu entwickeln [10]. Inklusionszysten des ovariellen Stromas, die während der Ovulation entstehen, kommen nach Stimulation des Stromas durch Gonadotropine mit hohen lokalen Östrogenkonzentrationen in Berührung. Diese Theorie basiert auf den Beobachtungen von Biskind und Biskind, die im Jahre 1944 beobachteten, dass die Transplantation von Ovarien in die Milz erwachsener Ratten zur Entwicklung ovarieller Tumoren führte. Die Tumorgenese wurde auf die Metabolisierung von Östrogenen in der Leber und die daraus resultierende Erhöhung des Gonadotropinspiegels bei fehlendem negativen Feedback zurückgeführt [11]. Dies wird durch die Arbeit von Blaakaer et al. unterstützt. In ihrer Studie setzten sie Mäuse mit einer kongenitalen Oozytendefizienz ein, die dafür bekannt sind, bilaterale komplex-tubuläre Adenome zu entwickeln. Die Plasmaspiegel von LH und FSH steigen während der Tumorgenese in diesen Mäusen um das 4-Fache an. Wurden diese Tiere mit GnRH-Agonisten behandelt, wurde die Tumorentstehung in $100 \%$ der Fälle verhindert [12]. Diese Theorie wird dadurch unterstützt, dass postmenopausale Patientinnen, die hohe Gonadotropinspiegel aufweisen, ein erhöhtes Risiko für Ovarialkarzinome aufweisen.

\section{Androgen-/Progesteron-Hypothese}

Risch postulierte 1998, dass der Einfluss von Androgenen das Risiko für Ovarialkarzinome erhöhen kann, wohingegen Progesteroneinfluss dieses Risiko erniedrigt [13]. Das ovarielle Oberflächenepithel exprimiert Androgenrezeptoren. Außerdem wurden im epithelialen Stroma des Ovars, das die epithelialen Inklusionszysten umgibt und als potenzieller Ursprungsort von Ovarialkarzinomen gilt, relative hohe Androgenkonzentrationen detektiert. Im Tiermodell wurde für Ovarialtumoren ein testosteronabhängiges Wachstum gezeigt [14, 15]. Signifikant erhöhte Androstendion- und Dehydroepiandrostendionspiegel wurden bei Frauen mit Ovarialkarzinom beobachtet [16] Frauen mit Symptomen, die mit erhöhten Androgenserumspiegeln assoziiert sind, wie Akne, Hirsutismus oder erhöhter Taille-Hüft-Ratio, hatten ein erhöhtes Risiko, ein Ovarialkarzinom zu entwickeln [17-19]. Diese Theorie wird jedoch kontrovers diskutiert, nachdem in neueren Arbeiten keine Assoziation zwischen den vor Diagnose bestehenden Androgenserumspiegeln, dem Serumspiegel des sexualhormonbindenden Globulins (SHBG) und dem Ovarialkarzinomrisiko bestand [20-22].

Während einer Schwangerschaft, die einen bekannten protektiven Faktor für die Entwicklung von Ovarialkarzinomen darstellt, werden hohe Progesteronserumspiegel beobachtet. Die vermutete protektive Rolle von Progesteron bei der Entwicklung von Ovarialkarzinomen wird durch die Tatsache unterstützt, dass gestagenhaltige orale Kontrazeptiva das Risiko für ein Ovarialkarzinom senken.

\section{Reproduktive Faktoren}

$\nabla$

Menarchenalter und Menopausenalter

Eine aktuelle Metaanalyse zeigte eine signifikante inverse Assoziation zwischen dem Menarchealter und dem Risiko, ein Ovarialkarzinom zu entwickeln (RR 0,85, 95\%-KI 0,75-0,97) [23]. Außerdem weisen Frauen mit einer geschätzten kumulativen Lebensspanne mit menstruellen Zyklen von über 36 Jahren ein signifikant höheres Ovarialkarzinomrisiko auf als die mit einer Zeitspanne von weniger als 27 Jahren [24]. Bream et al. haben für jedes Jahr, um das die gesamte Lebensspanne mit menstruellen Zyklen reduziert wurde, eine Risikoreduktion für ein Ovarialkarzinom von 3\% gezeigt (HR 0,97, 95\%-KI 
Table 1 Association between reproductive factors and the risk for ovarian cancer.

\begin{tabular}{|ll|} 
& Strength of association \\
\hline Shorter menstrual lifespan & - \\
\hline Lactation & -- \\
\hline Parity & --- \\
\hline Infertility & $+/ 0^{*}$ \\
\hline PCOS & $+/ 0$ \\
\hline
\end{tabular}

+ : positive association with the risk of developing ovarian cancer

-: negative association with the risk of developing ovarian cancer

0 : no association with the risk of developing ovarian cancer

* depends on the underlying cause of infertility

ovarian cancer compared to premenopausal women [26]. A positive association between the risk for ovarian cancer and age at menopause was noted (> 52 vs. $\leq 47$ years: HR 1.46 , 95\% CI $1.06-$ 1.99) [24]. Overall, a higher age at menarche and a younger age at menopause decreased the risk for ovarian cancer ( $\bullet$ Table $\mathbf{1}$ ).

The ovulation theory offers the best explanation for this association as a shorter cumulative menstrual lifespan is accompanied by fewer ovulations. The gonadotropin theory is not sufficient as an explanation, as postmenopausal women have high FSH levels.

\section{Lactation}

Whittemore et al. collected the data from 12 American case-control studies published between 1956 and 1986. They were able to show that women who had breastfed their children had a lower risk of ovarian cancer than women who had never breastfed (OR $0.73,95 \%$ CI $0.51-1.00$ in the hospital-based studies, OR 0.81, 95\% CI 0.68-0.95 in den population-based studies) [28]. This corresponded to the results of a population-based study from Australia with data from 1092 cases and 1288 controls. This study showed an inverse association between lactation and the development of ovarian cancer with a relative risk of 0.77 (95\% CI 0.61-0.96) [29]. The initial months of lactation appear to offer higher protective benefits, as the reduction of risk decreases after 6-12 months (2.5 vs. $1.4 \%$ ) [28].

However, when the risk-reducing effect of lactation is compared for different histological subtypes of ovarian cancer, the data is inconsistent. Gates et al. reported a reduction of risk due to lactation for all investigated histological subtypes (serous, endometrioid, mucinous) with the strongest association found for mucinous ovarian cancer (RR 0.43 per year, 95\% CI 0.25-0.74) [30]. Other studies only found a risk reduction for non-mucinous ovarian cancers [26,31,32], and Jordon et al. reported that the reduction of risk was limited to serous ovarian cancers [29]. The diversity of results with regard to histological subtypes can be explained by the limited number of cases investigated in some of the studies.

In summary, lactation reduces the risk of ovarian cancer ( $\bullet$ Table 1). The fact that the risk-reducing effect is higher in the first few months compared to subsequent months of lactation correlates with both the ovulation theory and the gonadotropin theory. Inhibition of the pulsatile secretion of GnRH and LH results in anovulation with suppression of estradiol production [33]. Ovulatory cycles often start after a few months of lactation and the risk for ovarian cancer increases again. The cause of the reduced risk for ovarian cancer can be explained by the androgen/progesterone theory, as progesterone levels remain low during lactation.
0,95-0,99) [25]. Diese Assoziation konnte jedoch nur für nicht muzinöse Tumoren gezeigt werden [26,27]. Postmenopausale Frauen haben ein 2-fach erhöhtes Risiko, ein Ovarialkarzinom zu entwickeln, als prämenopausale Frauen [26]. Es wurde eine positive Assoziation zwischen diesem Risiko und dem Menopausenalter beobachtet (> 52 vs. $\leq 47$ Jahre: HR 1,46, 95\%-KI 1,06-1,99) [24]. Insgesamt erniedrigt ein höheres Menarchenalter und ein jüngeres Menopausenalter das Ovarialkarzinomrisiko (๑ Tab. 1).

Zur Erklärung dieser Assoziationen eignet sich die Ovulationshypothese am ehesten, da eine kürzere Lebensspanne mit Menstruationszyklen mit einer geringeren Anzahl an Ovulationen einhergeht. Die Gonadotropinhypothese ist für die Erklärung der Ergebnisse insuffizient, da in der Postmenopause hohe FSH-Spiegel vorhanden sind.

\section{Laktation}

Whittemore et al. sammelten die Daten von 12 amerikanischen Fallkontrollstudien, die zwischen 1956 und 1986 durchgeführt wurden und zeigten, dass Frauen, die in ihrem Leben gestillt hatten, ein geringeres Ovarialkarzinomrisiko hatten als diejenigen, die nie gestillt hatten (OR 0,73, 95\%-KI 0,51-1,00 in den krankenhausbezogenen Studien, OR 0,81, 95\%-KI 0,68-0,95 in den populationsbasierten Studien) [28]. Das stimmt mit den Ergebnissen einer populationsbasierten Studie aus Australien überein, die Daten von 1092 Fällen und 1288 Kontrollen beinhaltete. Sie zeigten eine inverse Assoziation zwischen Laktation und dem Auftreten eines Ovarialkarzinoms mit einem relativen Risiko von 0,77 (95\%-KI 0,61-0,96) [29]. Die initialen laktierenden Monate scheinen einen höheren protektiven Effekt zu haben, da die Risikoreduktion nach 6-12 Monaten abnimmt (2,5 vs. 1,4\%) [28]. Wenn man den risikoreduzierenden Effekt der Laktation für die verschiedenen histologischen Subtypen des Ovarialkarzinoms vergleicht, ist die Datenlage uneinheitlich. Gates et al. beobachteten eine Risikoreduktion durch Laktation für alle untersuchten histologischen Subtypen (serös, endometrioid, muzinös) mit der stärksten Assoziation für das muzinöse Ovarialkarzinom (RR 0,43 pro Jahr, 95\%-KI $0,25-0,74)[30]$. Andere konnten nur eine Risikoreduktion für nicht muzinöse Ovarialkarzinome zeigen [26,31,32], und Jordon et al. zeigten eine auf das seröse Ovarialkarzinom beschränkte Risikoreduktion [29]. Die Vielfalt der Ergebnisse bezüglich des histologischen Subtyps kann durch die geringen Fallzahlen in einigen Studien erklärt werden.

Zusammengefasst verringert Laktation das Risiko für ein Ovarialkarzinom ( Tab. 1). Die Tatsache, dass der risikoreduzierende Effekt in den ersten Monaten den der folgenden Monate übertrifft, korreliert mit der Ovulations- und der Gonadotropintheorie. Die komplette Inhibierung der pulsatilen Sekretion von GnRH und LH führt zu Anovulation und Unterdrückung der Östradiolproduktion [33]. Nach einigen Monaten der Laktation können wieder ovulatorische Zyklen einsetzen, und die Risikoreduktion für ein Ovarialkarzinom nimmt ab. Die Ursache für ein reduziertes Ovarialkarzinomrisiko kann durch die Androgen-/Progesteron-Theorie erklärt werden, da die Progesteronspiegel während der Laktation niedrig bleiben.

\section{Parität}

In einer Metaanalyse von 12 amerikanischen Fallkontrollstudien beschreiben Whittemore et al. eine Risikoreduktion für ein Ovarialkarzinom von $40 \%$ nach der ersten Schwangerschaft [28]. Das stimmt mit den Daten von Riman et al. überein, die ein reduziertes Ovarialkarzinomrisiko für Primiparae verglichen mit Nulliparae beobachtet haben (OR 0,61, 95\%-KI 0,46-0,81) [34]. Der protektive Effekt erhöht sich mit der Anzahl der Geburten [28,34]. Den höchsten protektiven Effekt hat allerdings die erste ausgetragene Schwangerschaft. Jede weitere Schwangerschaft führt zu einer ähnlichen Risikoreduktion 
Parity

In a meta-analysis of 12 American case-control studies, Whittemore et al. reported a reduction of risk for ovarian cancer of $40 \%$ after the first pregnancy [28]. This corresponds to the data of Riman et al., who found a reduced risk of ovarian cancer in primiparae compared with nulliparae (OR 0.61, 95\% CI 0.46-0.81) [34]. The protective effect even increased with the number of births $[28,34]$. However, the first pregnancy carried to term had the highest protective effect. Every additional pregnancy similarly reduced the risk by about $14 \%$ [28]. This risk-reducing effect was also found after miscarriage although the effect is lower (OR 0.93) compared to the effect after pregnancy carried to term (OR 0.87) [28]. The impact of age at first pregnancy is disputed as the results of studies published to date are inconsistent $[28,34,35]$. In some studies, a reduced risk of ovarian cancer associated with parity is exclusively described for non-mucinous ovarian carcinoma $[25,27,36-38]$, while other studies report a similar risk-reducing effect for all histological subtypes of ovarian cancer [26, 39]. Jordan et al. found that pregnancies associated with different hormonal milieux had different effects on the risk of developing ovarian cancer and that some of these associations varied depending on the histological subtype. Thus, they found that women who bore only boys had a 2-fold increased risk for mucinous ovarian cancer (OR 2.19, 95\% Cl 1.15-4.17) [40].

Parity is a strong protective factor against the risk for ovarian cancer ( Table $\mathbf{1}$ ). This can be accounted for by the ovulation theory, as every pregnancy is accompanied by anovulation. In addition, the release of gonadotropins from the pituitary is suppressed for some time during pregnancy, confirming the gonadotropin theory. The progesterone theory could also serve as a basis to explain the protective effect of parity.

\section{Infertility}

Nulliparity is considered a risk factor for ovarian cancer ( Table 1). The question therefore arises whether this association is the result of a lack of pregnancy-associated effects or is induced by infertility-associated pathologies. Numerous cohort and casecontrol studies were done to resolve this question, but the results of some of the studies are controversial.

In a cohort study, Brinton et al. investigated 2335 women evaluated for infertility at the Mayo Clinic and found no increased risk of ovarian cancer (standardised incidence ratio [SIR] 1.3, $95 \% \mathrm{CI} 0.6-2$ ) [41]. This corresponds to the data of the meta-analysis by Whittemore et al. Unmarried nulligravid women were assigned to one group based on the assumption that they had no wish or no opportunity to become pregnant. Married nulligravid women were assumed to be infertile. When the groups were compared to one another, the latter group was not found to have an increased risk for ovarian cancer [28]. The Cancer Prevention Study II also showed no significant increase in the risk for ovarian cancer in patients with self-reported infertility (RR 1.1, 95\% CI $0.9-1.3)$ [42].

Other studies found an increased risk for ovarian cancer in subgroup analysis. Ness et al. carried out a pooled analysis of 8 case-control studies, investigating the data on nulligravid women who had sought medical help for infertility; the study found no significant increase in the risk for ovarian cancer (OR 1.19, 95\% CI 0.91-1.55). But additional analysis carried out among women who attempted to become pregnant for prolonged periods of time showed an increased risk of ovarian cancer, particularly among nulligravid women. Attempts to become pregnant for more than 5 years resulted in a 2.7-fold increase in the risk for um etwa 14\% [28]. Der risikoreduzierende Effekt kann auch nach Aborten beobachtet werden, wobei die Wirkung dadurch mit einer OR von 0,93 verglichen mit 0,87 bis zum Termin ausgetragener Schwangerschaften geringer ausfällt [28]. Der Effekt des Alters bei der ersten Geburt ist umstritten, die Ergebnisse in den veröffentlichten Studien sind widersprüchlich $[28,34,35]$. Laut einigen Arbeiten wird ein paritätsassoziiertes reduziertes Ovarialkarzinomrisiko ausschließlich für nicht muzinöse Ovarialkarzinome beschrieben [25, 27,36-38], andere zeigten einen ähnlichen risikoreduzierenden Effekt für alle histologischen Subtypen des Ovarialkarzinoms $[26,39]$. Jordan et al. fanden, dass Schwangerschaften mit unterschiedlicher hormoneller Umgebung sich verschieden auf das Ovarialkarzinomrisiko auswirken können und dass einige dieser Assoziationen mit dem histologischen Subtyp variieren können. So wurde eine 2-fache Erhöhung des Risikos für ein muzinöses Ovarialkarzinom beobachtet, wenn ausschließlich männliche Kinder ausgetragen wurden (OR 2,19, 95\%-KI 1,15-4,17) [40].

Parität ist ein stark protektiver Faktor für das Ovarialkarzinomrisiko ( Tab. 1). Dies lässt sich durch die Ovulationstheorie erklären, da jede Schwangerschaft mit Anovulation verbunden ist. Außerdem unterdrückt eine Schwangerschaft die Freisetzung von Gonadotropinen aus der Hypophyse über einen gewissen Zeitraum und die Gonadotropintheorie wird bestätigt. Auch die Progesterontheorie könnte die Grundlage für die protektive Wirkung von Parität sein.

\section{Infertilität}

Nulliparität gilt als Risikofaktor für die Entwicklung eines Ovarialkarzinoms ( Tab. 1). Daher stellt sich die Frage, ob diese Assoziation die Folge eines Mangels an schwangerschaftsassoziierten protektiven Effekten ist oder durch mit Infertilität assoziierten Pathologien induziert wird. Um diese Frage zu klären, wurden zahlreiche Kohortenund Fallkontrollstudien durchgeführt, die zum Teil kontroverse Ergebnisse hervorbrachten.

Brinton et al. beurteilten in ihrer Kohortenstudie 2335 Frauen, bei denen in der Mayo-Klinik eine Infertilität diagnostiziert wurde, und beobachteten kein erhöhtes Ovarialkarzinomrisiko (standardisierte Inzidenzratio [SIR] 1,3, 95\%-KI 0,6-2) [41]. Die Daten der Metaanalyse von Whittemore et al. passen dazu. Unverheiratete Nulligravidae wurden in eine Gruppe eingeteilt, von der angenommen wurde, dass sie keinen Wunsch oder keine Möglichkeit hatten, schwanger zu werden. Verheirateten Nulligravidae wurde Infertilität unterstellt. Wurden diese Gruppen miteinander verglichen, zeigte sich kein erhöhtes Ovarialkarzinomrisiko für letztere [28]. Die „Cancer Prevention Study II“ zeigte keine signifikante Erhöhung des Ovarialkarzinomrisikos bei Patientinnen mit Eigenangaben von Infertilität (RR 1,1, 95\%-KI 0,91,3) [42].

Andere zeigten in Subgruppenanalysen ein erhöhtes Risiko für die Entwicklung eines Ovarialkarzinoms:

Ness et al. führten eine gepoolte Analyse von 8 Fallkontrollstudien durch, in denen sie Nulligravidae untersucht haben, die aufgrund von Infertilität medizinische Hilfe in Anspruch genommen haben, und beobachteten keine signifikante Erhöhung des Ovarialkarzinomrisikos (OR 1,19, 95\%-KI 0,91-1,55). Weiterführende Analysen bezüglich prolongierter Episoden mit Versuchen, schwanger zu werden, ergaben ein erhöhtes Ovarialkarzinomrisiko, vor allem für Nulligravidae. Versuche, schwanger zu werden, die über 5 Jahre andauerten, führten zu einer 2,7-fachen Erhöhung des Ovarialkarzinomrisikos verglichen mit denen, die nach weniger als einem Jahr schwanger wurden (95\%-KI 1,91-3,74) [43].

Allerdings existieren auch Arbeiten, die eine klare Erhöhung des Ovarialkarzinomrisikos bei infertilen Frauen zeigen: 
ovarian cancer compared to women who attempted to become pregnant for less than 1 year (95\% CI 1.91-3.74) [43].

But there are also a number of studies which show that the risk for ovarian cancer is clearly increased in infertile women. Rossing et al. carried out a population-based case-control study of women between the ages of 35 and 54 years. The risk for ovarian cancer was highest for nulliparous women with a history of infertility whose infertility only became manifest relatively late in their reproductive life (first infertility at age 30 years and above: OR 2.2, 95\% CI 1.1-4.5) [44].

A Danish cohort study of 54362 infertile women referred to Danish fertility clinics between 1963 and 1998 found a clearly increased risk in these women. Significantly increased SIRs for ovarian cancer were observed after adjusting for parity status (SIR 1.46, 95\% CI 1.24-1.71) [45]. In this study, the risk for developing ovarian cancer was increased both for women after pregnancy and for nulligravid women (SIR 1.33, 95\% CI 1.04-1.68), but the increase was more pronounced in the latter group (SIR $1.60,95 \%$ CI 1.28-1.99) [45]. Tworoger et al. also described an increased risk for ovarian cancer in women who attempted unsuccessfully for at least 2 years to become pregnant (RR 1.36, 95\% CI 1.07-1.75) irrespective of a subsequent pregnancy.

Various research groups have reported different risk levels for ovarian cancer, depending on the cause of infertility. As described above, Rossing et al. reported an increased risk for ovarian cancer for nulligravid women but could not find a correlation with the cause of infertility [44]. Venn et al. carried out a cohort study of 29700 women and showed that women with unexplained infertility had significantly higher rates of ovarian cancer than expected (SIR 4.59, 95\% CI 1.91-11.0) [46]. Unexplained infertility was also found to increase the risk for ovarian cancer in the study by Ness et al. (OR 1.19, 95\% CI 1.00-1.40), and they additionally reported an increased risk for women with endometriosis as the cause of infertility (OR 1.73, 95\% CI 1.10-2.71) [43]. The association between endometriosis and individual histological subtypes of ovarian cancer was also the subject of a pooled analysis of 13 case-control studies by Pearce et al. [47]. Patients with endometriosis had a significantly increased risk of developing clear cell (20.2\% of cases vs. $6.2 \%$ of controls, OR 3.05, 95\% CI 2.43-3.83, $\mathrm{p}<0.0001$ ), low-grade serous (9.2 vs. $6.2 \%$, OR $2.11,95 \% \mathrm{CI}$ $1.39-3.2, \mathrm{p}<0.0001$ ) and endometrioid ovarian cancer (13.9 vs. $6.2 \%$, OR $2.04,95 \%$ CI 1.67-2.48). They found no association between endometriosis and the risk of mucinous or high-grade serous ovarian cancer [47].

There is still too little known about potential links between infertility and the risk for individual histological subtypes. The abovementioned Danish cohort study reported an increased risk for non-mucinous ovarian cancer [45]. However, Rossing et al. found no differences in the risk of infertile women developing mucinous or non-mucinous ovarian cancer [44].

\section{PCO syndrome}

In their case-control study, Schildkraut et al. compared 476 cases with ovarian cancer with 4081 controls. Among the women with ovarian cancer, 7 had been diagnosed with polycystic ovary syndrome (PCOS), while only 24 of controls had PCOS. The study found a 2.5-fold increased risk for ovarian cancer in women with PCOS [48]. Chittenden et al. carried out a systematic review of data published between 1968 and 2008; their results support the findings of Schildkraut et al. (OR 2.52, 95\% CI 1.08-5.89) [49]. Other case-control studies and prospective studies have not been able to demonstrate this association $[20,50,51]$ ( Table 1).
Rossing et al. führten eine populationsbasierte Fallkontrollstudie bei Frauen zwischen 35 und 54 Jahren durch. Das Ovarialkarzinomrisiko war bei Nulligravidae am höchsten, wenn deren Infertilität erst relativ spät im reproduktiven Leben manifest wurde (für die erste Schwangerschaft im Alter von über 30 Jahren: OR 2,2, 95\%-KI 1,14,5) [44].

Ein deutlich erhöhtes Risiko wurde auch in einer dänischen Kohortenstudie mit 54362 infertilen Frauen beobachtet, die sich zwischen 1963 und 1998 an dänische Fertilitätskliniken wandten. Nach Angleichung des Paritätsstatus zeigten sich signifikant höhere SIRs für Ovarialkarzinome (SIR 1,46, 95\%-KI 1,24-1,71) [45]. In dieser Arbeit war das Ovarialkarzinom sowohl für Frauen nach Partus als auch für Nulligravidae erhöht (SIR 1,33, 95\%-KI 1,04-1,68), aber für Letztere ausgeprägter (SIR 1,60, 95\%-KI 1,28-1,99) [45]. Auch Tworoger et al. beschrieben ein erhöhtes Risiko für ein Ovarialkarzinom für Frauen, die über mindestens 2 Jahre ohne Erfolg eine Schwangerschaft anstrebten (RR 1,36, 95\%-KI 1,07-1,75) unabhängig von der Parität.

Außerdem gab es Gruppen, die je nach Infertilitätsursache unterschiedliche Risikostufen für ein Ovarialkarzinom beschrieben:

Rossing et al., die wie oben erläutert ein erhöhtes Ovarialkarzinomrisiko für Nulliparae zeigten, konnten keinen Zusammenhang mit der Infertilitätsursache herstellen [44]. Venn et al. führten eine Kohortenstudie bestehend aus 29700 Frauen durch und zeigten, dass diejenigen mit einer unerklärten Infertilität signifikant höhere Ovarialkarzinomraten aufwiesen als erwartet (SIR 4,59, 95\%-KI 1,9111,0) [46]. Unerklärte Infertilität erhöhte das Ovarialkarzinomrisiko auch in der Arbeit von Ness et al. (OR 1,19, 95\%-KI 1,00-1,40), wobei sie zusätzlich ein erhöhtes Risiko für Frauen zeigten, bei denen Endometriose der Infertilitätsgrund waren (OR 1,73, 95\%-KI 1,10-2,71) [43]. Der Zusammenhang zwischen Endometriose und den einzelnen histologischen Subtypen des Ovarialkarzinoms war auch Grundlage der gepoolten Analyse von 13 Fallkontrollstudien von Pearce et al. [47]. Patientinnen mit Endometriose haben ein signifikant erhöhtes Risiko, ein klarzelliges (20,2\% der Fälle vs. 6,2\% der Kontrollen, OR $3,05,95 \%$-KI 2,43-3,83, p < 0,0001) low-grade seröses (9,2 vs. 6,2\%, OR 2,11, 95\%-KI 1,39-3,2, p<0,0001) und endometrioides Ovarialkarzinom zu entwickeln (13,9 vs. 6,2\%, OR 2,04, 95\%-KI 1,67-2,48). Es wurde kein Zusammenhang zwischen Endometriose und dem Risiko für ein muzinöses oder high-grade seröses Ovarialkarzinom gefunden [47].

Was Infertilität und das Risiko für die einzelnen histologischen Subtypen angeht, ist noch wenig bekannt. Die oben erwähnte dänische Kohortenstudie beobachtete ein erhöhtes Risiko für nicht muzinöse Ovarialkarzinome [45]. Rossing et al. hingegen fanden keinen Unterschied bezüglich des Risikos für muzinöse und nicht muzinöse Ovarialkarzinome bei infertilen Frauen [44].

\section{PCO-Syndrom}

Schildkraut et al. verglichen in ihrer Fallkontrollstudie 476 Fälle von Ovarialkarzinomen mit 4081 Kontrollen. Unter den Ovarialkarzinompatientinnen hatten 7 ein diagnostiziertes Syndrom polyzystischer Ovarien (PCOS), wohingegen nur 24 der Kontrollen an einem PCOS litten. Es zeigte sich in dieser Studie ein 2,5-fach erhöhtes Risiko für ein Ovarialkarzinom bei Frauen mit PCOS [48]. Die Ergebnisse von Chittenden et al., die eine systematische Übersichtsarbeit mit den zwischen 1968 und 2008 publizierten Daten durchgeführt haben, unterstützen diese Daten (OR 2,52, 95\%-KI 1,08-5,89) [49]. Andere Fallkontrollstudien und prospektive Studien konnten diesen Zusammenhang nicht zeigen $[20,50,51]$ ( Tab. 1 ).

Frauen mit PCOS weisen eine höhere Rate anovulatorischer Zyklen auf. Daher ist eine Erklärung eines erhöhten Ovarialkarzinomrisikos bei Frauen mit PCOS durch die Ovulationstheorie nicht möglich. Bei 
Women with PCOS have higher rates of anovulatory cycles. The ovulation theory is therefore not useful to explain the postulated increased risk for ovarian cancer in women with PCOS. Hypothalamic-pituitary regulation of gonadotropin secretion is abnormal in women with PCOS [52], basal concentrations of LH, androstenedione and estrone are significantly higher and FSH concentrations significantly lower than in controls $(p<0.05)$ [53]. The increased amplitude of $\mathrm{LH}$ pulses can result in persistent LH stimulation of the ovaries, leading to increased ovarian androgen secretion and disrupting follicle maturation. According to the gonadotropin theory, persistently high LH levels promote the development of ovarian cancer. The increased risk for ovarian cancer in women with PCOS can be explained by the progesterone/androgen theory as progesterone levels remain low during anovulatory cycles.

\section{Summary and Outlook}

$\nabla$

Ovarian cancer is characterised by its potential for aggressive local invasion. But despite intensive research in recent decades, the aetiology and pathogenesis of this tumour entity is only partly understood. Ovarian carcinomas are potentially endocrine-regulated cancers. The association between reproductive factors and ovarian cancer risk has been investigated in numerous cohort and case-control studies. However, only a few of these studies have provided conclusive results. A shorter menstrual lifespan, parity and lactation have all been found to be protective factors against ovarian cancer. It is still unclear to what extent infertility is associated with the development of ovarian cancer. The different causes of infertility must be taken into account in future investigations to achieve a better understanding of the association between infertility and ovarian cancer. A number of theories have been proposed to explain the association between reproductive factors and ovarian cancer; however none of them offers a comprehensive explanation.

Reproductive factors affect the risk of developing ovarian cancer as do demographic and life-style factors [54,55]. Twin studies have shown that around $22 \%$ of the risk for ovarian cancer can be ascribed to inherited genetic factors [56]. In recent years, a number of genome-wide association studies were done which detected single nucleotide polymorphisms (SNPs) and subsequently examined their association with various investigated characteristics [56-61]. These studies support the hypothesis that many characteristics are at least partially caused by genetic mutations [56,61]. The Cancer Genome Atlas (TCGA) project investigated the mRNA expression, miRNA expression, promoter methylation and DNA copy number in 489 high-grade serous ovarian adenocarcinomas [62]. 96\% of all investigated tumours had p53 mutation, and germline mutations in BRCA 1/2 or other somatic aberrations were present in $22 \%$ of tumours [62].

Recent results have shown that the various histological subtypes of ovarian cancer represent different tumour entities with different cellular origins. The epithelium of the Fallopian tube is the source of high-grade and low-grade serous cancers. Endometrioid and clear cell cancers develop from endometrioid lesions, and one possible origin of mucinous tumours could be transitional-cell epithelial nests in paraovarian locations at the tuboperitoneal junction [2]. These different cellular origins could be the explanation for the varied effects of reproductive factors on different types of ovarian cancer. A differentiated approach which
Frauen mit PCOS ist die durch die Hypothalamus-Hypophysen-Achse regulierte Gonadotropinsekretion abnorm [52], die basalen Konzentrationen von LH, Androstendion und Östron signifikant höher und die FSH-Konzentration signifikant niedriger als in den Kontrollpatientinnen $(p<0,05)$ [53]. Die erhöhte LH-Pulsfrequenz kann zu einer persistierenden LH-Stimulation der Ovarien und dadurch zu einer erhöhten ovariellen Androgensekretion und beeinträchtiger Follikelreifung führen. Gemäß der Gonadotropintheorie unterstützen persistierend hohe LH-Spiegel die Ovarialkarzinomentstehung. Außerdem kann ein erhöhtes Ovarialkarzinomrisiko bei Frauen mit PCOS durch die Progesteron-/Androgen-Theorie erklärt werden, da die Progesteronspiegel bei Anovulation niedrig bleiben.

\section{Zusammenfassung und Ausblick \\ $\nabla$}

Das Ovarialkarzinom zeichnet sich durch sein aggressives lokales Invasionspotenzial aus. Trotz intensiver wissenschaftlicher Bemühungen während der letzten Jahrzehnte wird die Ätiologie und Pathogenese dieser Tumorentität nur zum Teil verstanden. Das Ovarialkarzinom ist ein potenziell endokrin regulierter Tumor. Der Zusammenhang zwischen reproduktiven Faktoren und dem Risiko für ein Ovarialkarzinom wurde in zahlreichen Kohorten- und Fallkontrollstudien untersucht. Eindeutige Schlüsse konnten jedoch nur in wenigen Fällen gezogen werden. Eine kurze Lebensspanne mit menstruellen Zyklen, Parität und Laktation wirken für ein Ovarialkarzinom protektiv. Inwieweit Infertilität mit dem Risiko einer Ovarialkarzinomentstehung zusammenhängt, bleibt unklar. Es scheint unabdingbar, die verschiedenen Ursachen für Infertilität in diese Untersuchungen einzubeziehen, um die Beziehung zwischen Infertilität und Ovarialkarzinom besser zu verstehen. Es existieren einige Theorien, die den Zusammenhang zwischen reproduktiven Faktoren und der Entstehung einer Ovarialkarzinoms interpretieren, keine von ihnen kann jedoch eine vollständige Erklärung liefern.

Reproduktive Faktoren beeinflussen ebenso wie demografische und Lebensstilfaktoren das Risiko, ein Ovarialkarzinom zu entwickeln $[54,55]$. Zwillingsstudien haben gezeigt, dass etwa $22 \%$ des Ovarialkarzinomrisikos erblichen Faktoren zugeschrieben werden können [56]. In den letzten Jahren werden zunehmend genomweite Assoziationsstudien durchgeführt, die Einzelnukleotid-Polymorphismen (SNPs) im gesamten Genom detektieren und anschließend deren Assoziation mit der gesuchten Eigenschaft untersuchen [56-61]. Diese Arbeiten unterstützen die Hypothese, dass viele Merkmale, zumindest teilweise, durch genetische Variationen hervorgerufen werden [56,61]. Das „Cancer Genome Atlas“-(TCGA-)Projekt analysierte 489 high-grade seröse Ovarialkarzinome bezüglich ihrer mRNA-Expression, der miRNA-Expression, der Promotermethylierung und der DNA-Kopienzahl [62]. 96\% aller untersuchten Tumoren wiesen eine p53-Mutation auf und BRCA 1/2 lag aufgrund einer Kombination aus Keimzellmutationen und somatischen Mutationen in 22\% der Tumoren mutiert vor [62].

Aktuelle Ergebnisse zeigen, dass die verschiedenen histologischen Subtypen des Ovarialkarzinoms unterschiedliche Tumorentitäten darstellen, die sich von verschiedenen Ursprungszellen ableiten. Seröse High-Grade- und Low-Grade-Karzinome haben ihren Ursprung im Epithel der Tuba uterina. Endometrioide und klarzellige Karzinome entwickeln sich aus endometrioiden Läsionen und der mögliche Ursprung muzinöser Tumoren scheinen transitionalzellige epitheliale Nester zu sein, die paraovariell an der tuboperitonealen Kontaktstelle lokalisiert sind [2]. Diese unterschiedlichen Ursprungszellen können eine Erklärung für die vielfältigen Effekte reproduktiver Faktoren auf die verschiedenen Ovarialkarzinomtypen liefern. Daher ist ein diffe- 
takes account of the differences in ovarian cancer entities is therefore essential for future studies.

\section{Conclusion}

Ovarian epithelial cancer is the sixth most common cancer in women in industrialised countries.

Reproductive factors play a role in the risk for ovarian cancer.

A short menstrual lifespan, lactation and parity all reduce the risk of developing ovarian cancer.

To date, there is no clear association between infertility and the risk of ovarian cancer; however, it does appear to depend on the cause of infertility.

\section{Conflict of Interest}

$\nabla$

None.

\section{References}

1 Jemal A, Bray F, Center MM et al. Global cancer statistics. CA Cancer J Clin 2011; 61: 69-90

2 Kurman RJ, Shih Ie M. Molecular pathogenesis and extraovarian origin of epithelial ovarian cancer - shifting the paradigm. Hum Pathol 2011; 42: 918-931

3 Fathalla MF. Incessant ovulation - a factor in ovarian neoplasia? Lancet 1971; $2: 163$

4 Schildkraut JM, Bastos E, Berchuck A. Relationship between lifetime ovulatory cycles and overexpression of mutant p 53 in epithelial ovarian cancer. J Natl Cancer Inst 1997; 89: 932-938

5 Kuhn E, Kurman RJ, Shih IM. Ovarian cancer is an imported disease: fact or fiction? Curr Obstet Gynecol Rep 2012; 1: 1-9

6 Przybycin CG, Kurman RJ, Ronnett BM et al. Are all pelvic (nonuterine) serous carcinomas of tubal origin? Am J Surg Pathol 2010; 34: 14071416

7 Kuhn E, Kurman RJ, Vang R et al. TP53 mutations in serous tubal intraepithelial carcinoma and concurrent pelvic high-grade serous carcinoma - evidence supporting the clonal relationship of the two lesions. J Pathol 2012; 226: 421-426

8 Marquez RT, Baggerly KA, Patterson AP et al. Patterns of gene expression in different histotypes of epithelial ovarian cancer correlate with those in normal fallopian tube, endometrium, and colon. Clin Cancer Res 2005; 11: 6116-6126

9 Murdoch WJ, Martinchick JF. Oxidative damage to DNA of ovarian surface epithelial cells affected by ovulation: carcinogenic implication and chemoprevention. Exp Biol Med (Maywood) 2004; 229: 546-552

10 Cramer DW, Welch WR. Determinants of ovarian cancer risk. II. Inferences regarding pathogenesis. J Natl Cancer Inst 1983; 71: 717-721

11 Vanderhyden BC, Shaw TJ, Ethier JF. Animal models of ovarian cancer. Reprod Biol Endocrinol 2003; 1: 67

12 Blaakaer J, Baeksted M, Micic S et al. Gonadotropin-releasing hormone agonist suppression of ovarian tumorigenesis in mice of the $\mathrm{Wx} / \mathrm{Wv}$ genotype. Biol Reprod 1995; 53: 775-779

13 Risch HA. Hormonal etiology of epithelial ovarian cancer, with a hypothesis concerning the role of androgens and progesterone. J Natl Cancer Inst 1998; 90: 1774-1786

14 Silva EG, Tornos C, Fritsche jr. HA et al. The induction of benign epithelial neoplasms of the ovaries of guinea pigs by testosterone stimulation: a potential animal model. Mod Pathol 1997; 10: 879-883

15 Nishizuka Y, Sakakura T, Tsujimura T et al. Steroid biosynthesis in vitro by dysgenetic ovaries induced by neonatal thymectomy in mice. Endocrinology 1973; 93: 786-792

16 Helzlsouer KJ, Alberg AJ, Gordon GB et al. Serum gonadotropins and steroid hormones and the development of ovarian cancer. JAMA 1995; 274: 1926-1930

17 Wynder EL, Dodo H, Barber HR. Epidemiology of cancer of the ovary. Cancer 1969; 23: 352-370 renzierter Ansatz, der die verschiedenen Ovarialkarzinomentitäten einbezieht, für die künftigen Studien unerlässlich.

\section{Fazit für die Praxis}

$\nabla$

Das epitheliale Ovarialkarzinom ist die sechsthäufigste Krebsform bei Frauen in Industrieländern.

Reproduktive Faktoren spielen eine relevante Rolle für das Ovarialkarzinomrisiko.

Eine kurze Lebensspanne mit menstruellen Zyklen, Laktation und Parität reduzieren das Risiko für Ovarialkarzinome.

Es besteht bisher kein klarer Zusammenhang zwischen Infertilität und dem Risiko für ein Ovarialkarzinom, er scheint jedoch von der Infertilitätsursache abhängig zu sein.

\section{Interessenkonflikt}

$\nabla$

Nein.

18 Sonnichsen AC, Lindlacher U, Richter WO et al. [Obesity, body fat distribution and the incidence of breast, cervical, endometrial and ovarian carcinomas]. Dtsch Med Wochenschr 1990; 115: 1906-1910

19 [Anonym]. Ovarian cancer and body size: individual participant metaanalysis including 25,157 women with ovarian cancer from 47 epidemiological studies. PLoS Med 2012; 9: e1001200

20 Olsen CM, Green AC, Nagle CM et al. Epithelial ovarian cancer: testing the 'androgens hypothesis'. Endocr Relat Cancer 2008; 15: 1061-1068

21 Kotsopoulos J, Baer HJ, Tworoger SS. Anthropometric measures and risk of epithelial ovarian cancer: results from the nurses' health study. Obesity (Silver Spring) 2010; 18: 1625-1631

22 Lahmann PH, Cust AE, Friedenreich CM et al. Anthropometric measures and epithelial ovarian cancer risk in the European Prospective Investigation into Cancer and Nutrition. Int J Cancer 2010; 126: 2404-2415

23 Gong TT, Wu OJ, Vogtmann E et al. Age at menarche and risk of ovarian cancer: a meta-analysis of epidemiological studies. Int J Cancer 2013; 132: $2894-2900$

24 Tsilidis KK, Allen NE, Key TJ et al. Oral contraceptive use and reproductive factors and risk of ovarian cancer in the European Prospective Investigation into Cancer and Nutrition. Br J Cancer 2011; 105: 14361442

25 Braem MG, Onland-Moret NC, van den Brandt PA et al. Reproductive and hormonal factors in association with ovarian cancer in the Netherlands cohort study. Am J Epidemiol 2010; 172: 1181-1189

26 Tung KH, Goodman MT, Wu AH et al. Reproductive factors and epithelial ovarian cancer risk by histologic type: a multiethnic case-control study. Am J Epidemiol 2003; 158: 629-638

27 Soegaard M, Jensen A, Hogdall E et al. Different risk factor profiles for mucinous and nonmucinous ovarian cancer: results from the Danish MALOVA study. Cancer Epidemiol Biomarkers Prev 2007; 16: 11601166

28 Whittemore AS, Harris R, Itnyre J. Characteristics relating to ovarian cancer risk: collaborative analysis of 12 US case-control studies. II. Invasive epithelial ovarian cancers in white women. Collaborative Ovarian Cancer Group. Am J Epidemiol 1992; 136: 1184-1203

29 Jordan SJ, Siskind V, C Green A et al. Breastfeeding and risk of epithelial ovarian cancer. Cancer Causes Control 2010; 21: 109-116

30 Gates MA, Rosner BA, Hecht JL et al. Risk factors for epithelial ovarian cancer by histologic subtype. Am J Epidemiol 2010; 171: 45-53

31 Titus-Ernstoff L, Perez K, Cramer DW et al. Menstrual and reproductive factors in relation to ovarian cancer risk. Br J Cancer 2001; 84: 714-721

32 Purdie DM, Siskind V, Bain CJ et al. Reproduction-related risk factors for mucinous and nonmucinous epithelial ovarian cancer. Am J Epidemiol 2001; 153: 860-864

33 McNeilly AS. Lactational control of reproduction. Reprod Fertil Dev 2001; 13: 583-590 
34 Riman T, Dickman PW, Nilsson S et al. Risk factors for invasive epithelial ovarian cancer: results from a Swedish case-control study. Am J Epidemiol 2002; 156: 363-373

35 Merrill RM, Fugal S, Novilla LB et al. Cancer risk associated with early and late maternal age at first birth. Gynecol Oncol 2005; 96: 583-593

36 Risch HA, Marrett LD, Jain M et al. Differences in risk factors for epithelial ovarian cancer by histologic type. Results of a case-control study. Am J Epidemiol 1996; 144: 363-372

37 Kvale G, Heuch I, Nilssen S et al. Reproductive factors and risk of ovarian cancer: a prospective study. Int J Cancer 1988; 42: 246-251

38 Whiteman DC, Murphy MF, Cook LS et al. Multiple births and risk of epithelial ovarian cancer. J Natl Cancer Inst 2000; 92: 1172-1177

39 Kurian AW, Balise RR, McGuire $V$ et al. Histologic types of epithelial ovarian cancer: have they different risk factors? Gynecol Oncol 2005; 96: $520-530$

40 Jordan SJ, Green AC, Nagle CM et al. Beyond parity: association of ovarian cancer with length of gestation and offspring characteristics. Am J Epidemiol 2009; 170: 607-614

41 Brinton LA, Melton LJ 3rd, Malkasian jr. GD et al. Cancer risk after evaluation for infertility. Am J Epidemiol 1989; 129: 712-722

42 Rodriguez C, Tatham LM, Calle EE et al. Infertility and risk of fatal ovarian cancer in a prospective cohort of US women. Cancer Causes Control 1998; 9: 645-651

43 Ness RB, Cramer DW, Goodman MT et al. Infertility, fertility drugs, and ovarian cancer: a pooled analysis of case-control studies. Am J Epidemiol 2002; 155: 217-224

44 Rossing MA, Tang MT, Flagg EW et al. A case-control study of ovarian cancer in relation to infertility and the use of ovulation-inducing drugs. Am J Epidemiol 2004; 160: 1070-1078

45 Jensen A, Sharif H, Olsen JH et al. Risk of breast cancer and gynecologic cancers in a large population of nearly 50,000 infertile Danish women. Am J Epidemiol 2008; 168: 49-57

46 Venn A, Watson L, Bruinsma F et al. Risk of cancer after use of fertility drugs with in-vitro fertilisation. Lancet 1999; 354: 1586-1590

47 Pearce CL, Templeman C, Rossing MA et al. Association between endometriosis and risk of histological subtypes of ovarian cancer: a pooled analysis of case-control studies. Lancet Oncol 2012; 13: 385-394

48 Schildkraut JM, Schwingl PJ, Bastos E et al. Epithelial ovarian cancer risk among women with polycystic ovary syndrome. Obstet Gynecol 1996; 88: 554-559

49 Chittenden BG, Fullerton G, Maheshwari A et al. Polycystic ovary syndrome and the risk of gynaecological cancer: a systematic review. Reprod Biomed Online 2009; 19: 398-405
50 Pierpoint T, McKeigue PM, Isaacs AJ et al. Mortality of women with polycystic ovary syndrome at long-term follow-up. J Clin Epidemiol 1998; 51: 581-586

51 Brinton LA, Moghissi KS, Westhoff CL et al. Cancer risk among infertile women with androgen excess or menstrual disorders (including polycystic ovary syndrome). Fertil Steril 2010; 94: 1787-1792

52 Rebar R, Judd HL, Yen SS et al. Characterization of the inappropriate gonadotropin secretion in polycystic ovary syndrome. J Clin Invest 1976; 57: 1320-1329

53 Baird DT, Corker CS, Davidson DW et al. Pituitary-ovarian relationships in polycystic ovary syndrome. J Clin Endocrinol Metab 1977; 45: 798801

54 Rhiem K, Pfeifer K, Schmutzler RK et al. Risk-reducing surgery in women at risk for familial breast or ovarian cancer. Geburtsh Frauenheilk 2012; 72: 833-839

55 Waldmann A, Eisemann N, Katalinic A. Epidemiology of malignant cervical, corpus uteri and ovarian tumours - current data and epidemiological trends. Geburtsh Frauenheilk 2013; 73: 123-129

56 Bolton KL, Ganda C, Berchuck A et al. Role of common genetic variants in ovarian cancer susceptibility and outcome: progress to date from the Ovarian Cancer Association Consortium (OCAC). J Intern Med 2012; 271: $366-378$

57 Larson NB, Jenkins GD, Larson MC et al. Kernel canonical correlation analysis for assessing gene-gene interactions and application to ovarian cancer. Eur J Hum Genet 2013; DOI: 10.1038/ejhg.2013.69

58 Cicek MS, Koestler DC, Fridley BL et al. Epigenome-wide ovarian cancer analysis identifies a methylation profile differentiating clear-cell histology with epigenetic silencing of the HERG K+ channel. Hum Mol Genet 2013; [Epub ahead of print]

59 Pharoah PD, Tsai YY, Ramus SJ et al. GWAS meta-analysis and replication identifies three new susceptibility loci for ovarian cancer. Nat Genet 2013; 45: 362-370

60 Bojesen SE, Pooley KA, Johnatty SE et al. Multiple independent variants at the TERT locus are associated with telomere length and risks of breast and ovarian cancer. Nat Genet 2013; 45: 371-384

61 Fasching PA, Gayther S, Pearce L et al.; OCAC (Ovarian Cancer Association Consortium). Role of genetic polymorphisms and ovarian cancer susceptibility. Mol Oncol 2009; 3: 171-181

62 [Anonym]. Integrated genomic analyses of ovarian carcinoma. Nature 2011; 474: 609-615

Deutschsprachige Zusatzinformationen online abrufbar unter: www.thieme-connect.de/ejournals/toc/gebfra. 